(c) 2018 - ISSN 1807-2577

\title{
Affective relationships as predictors of TMD symptoms in young adults
}

\author{
Relações afetivas como preditoras de sintomas de DTM em adultos jovens
}

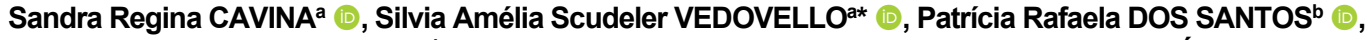 \\ Diego Patrik Alves CARNEIRO ${ }^{b}$ (D), Giovana Cherubini VENEZIANa ${ }^{\mathbb{D}}$, William CUSTÓDIOa ${ }^{\mathbb{D}}$, \\ Viviane Veroni DEGAN ${ }^{\mathrm{a}}$ (1) \\ ${ }^{\mathrm{a}} \mathrm{FHO}$ - Centro Universitário Hermínio Ometto, Departamento de Ortodontia, Araras, SP, Brasil \\ bUNICAMP - Universidade Estadual de Campinas, Faculdade de Odontologia, Piracicaba, SP, Brasil
}

\begin{abstract}
How to cite: Cavina SR, Vedovello SAS, Santos PR, Carneiro DPA, Venezian GC, Custódio W, et al. Affective relationships as predictors of TMD symptoms in young adults. Rev Odontol UNESP. 2021;50:e20210018. https://doi.org/10.1590/18072577.01821
\end{abstract}

\begin{abstract}
Resumo
Introdução: A dor orofacial é um sintoma crítico da DTM que pode influenciar a capacidade física e social. Objetivo: Avaliar a associação dos sintomas das desordens têmporomandibulares (DTM) com as relações afetivas e variáveis demográficas em adultos jovens. Material e método: Estudo transversal envolvendo 395 adultos jovens foi realizado. Os critérios diagnósticos para DTM, ansiedade e depressão foram coletados a partir de questionários. O Componente de Saúde Bucal do Índice de Necessidade de Tratamento Ortodôntico mensurou a necessidade de tratamento ortodôntico. Os questionários também continham questões relacionadas ao tratamento ortodôntico anterior. Modelos de regressão logística foram ajustados, estimando odds ratio bruto com os intervalos de confiança de $95 \%$. As variáveis com $p<0.20$ nas análises foram avaliadas em modelo de regressão logística múltipla, permanecendo as variáveis com $\mathrm{p} \leq 0.10$. Resultado: Não houve associação significativa dos sintomas de DTM com sexo, idade, uso de medicamentos para dor, tratamento ortodôntico prévio, necessidade de tratamento ortodôntico, ansiedade e depressão ( $p>0.05$ ). Indivíduos sem relacionamento afetivo têm 1.78 (IC95\%:0.99-3.17) vezes mais chance de relatar sintomas de DTM. Conclusão: Os relacionamentos afetivos mostraram associação com os sintomas de DTM em adultos jovens.
\end{abstract}

Descritores: Má oclusão; ansiedade e depressão; desordem temporomandibular; jovem adulto; mulher.

\begin{abstract}
Introduction: Orofacial pain is a critical TMD symptom that can influence physical and social capacity. Objective: To evaluate the association of temporomandibular disorders (TMD) symptoms with affective relationships and demographic variables in young adults. Material and method: A cross-sectional study involving 395 young adults was developed. Diagnostic Criteria for TMD, anxiety, and depression were collected from questionnaires. The Dental Health Component of the Index of Orthodontic Treatment Need measures the orthodontic treatment need. Questionnaires also contained questions related to the previous orthodontic treatment. Logistic regression models were adjusted, estimating crude odds ratio with the $95 \%$ confidence intervals. The variables with $\mathrm{p}<0.20$ in the analyses were assessed in a multiple logistic regression model, remaining with $\mathrm{p} \leq 0.10$. Result: There was no significant association of TMD symptoms with sex, age, medication use for pain, previous orthodontic treatment, orthodontic treatment need, anxiety, and depression ( $p>0.05)$. Individuals without an affective relationship are 1.78 (95\%CI: 0.99-3.17) times more likely to report TMD symptoms. Conclusion: Affective relationships showed an association with TMD symptoms in young adults.
\end{abstract}

Descriptors: Malocclusion; anxiety and depression; temporomandibular disorder; young adult; woman. 


\section{INTRODUCTION}

Orofacial pain may have social, psychological, and economic consequences on individuals and communities ${ }^{1}$. When untreated, it may lead to disability, increased risk of depression, sleep deprivation, reduced quality of life, and social isolation².

The prevalence of orofacial pain in the population is around $10 \%$ to $15 \%{ }^{3}$, and it is one of the main temporomandibular disorder (TMD) symptoms ${ }^{1}$. Individual with TMD may present several changes in the stomatognathic system caused by tooth wear, malocclusion, previous orthodontic treatment, inflammatory and infectious processes, trauma, stress, anxiety, and other psychogenic factors ${ }^{4}$. This strengthens the hypothesis that psychological disorders and psychosocial impairments are highly prevalent in TMD patients ${ }^{5}$ and may lead to increased muscle hyperactivity ${ }^{6}$. Hence, TMD refer to conditions affecting mastication and/or temporomandibular joint (TMJ) muscles, which are indicated as the leading cause of non-dental pain in the orofacial region, including head, face, and related structures.

Studies have suggested that symptoms related to TMD occur predominantly in young adults and women in a female: male ratio of $4: 1^{7,8}$. Moreover, this condition is more prevalent among women in their reproductive years - between 20 and 40 years old -, which are attributed to stress, social and cultural behavior, and effects related to hormonal characteristics ${ }^{7,9}$.

Despite the great number of studies investigating this association, such an issue remains controversial ${ }^{10}$. The current evidence suggests that TMD should be seen as a group of diseases with solid genetic factors and psychosocial aspects, which play a significant role in its incidence ${ }^{11}$. In addition, it is known that TMD may result from the interrelation of psych behavioral, occlusal, and neuromuscular factors. Thus, understanding the origin and characteristics of this disorder and planning the respective treatment is significant for understanding TMD ${ }^{12}$.

There is no report in the literature regarding the impact of affective relationships on the TMD symptoms among predisposing factors. However, considering the importance of psych behavioral aspects in TMD etiology, the stable union of couples provides a sort of stability in the sentimental context, consequently decreasing TMD symptoms ${ }^{12}$.

Considering the population of young adults and the multifactorial character of TMD, the hypothesis studied is that affective relationships influence TMD symptoms among young adults. Thus, the main objective was to evaluate the association of TMD symptoms with affective relationships and demographic variables in young adults.

\section{MATERIAL AND METHOD}

\section{Experimental Design}

The Research Ethics Committee approved this cross-sectional study (\# 2.324.935/2017). The participation was voluntary, and all subjects were informed about the examination procedures, and the confidentiality of the information collected was guaranteed. The subjects who agreed with their participation signed the free and informed consent form at the beginning of the study, produced according to the STROBE statement.

The minimum sample of 350 individuals was determined based on a previous pilot study $(\mathrm{n}=50)$ in the Epi info software (Centers for Disease Control and Prevention, Atlanta, GA, USA), considering a significance level of 5\%, power $80 \%$ Test and Effect Size 2.0. A simple probabilistic sampling procedure recruited randomly selected subjects within the target age group (20 to 30 years of age). Individuals with current or previous orthodontic treatment and a history of craniofacial fracture and orthognathic surgery were excluded from the study. The final sample 
included the participation of 395 young adults with an average age of 22 years. The study was carried out between March and June 2018.

The outcome was the presence of temporomandibular disorder (TMD) symptoms. The independent variables were classified into demographic (e.g., gender, age, marital status, children), use of medication for continuous and/or sporadic pain, orthodontic characteristics (e.g., current or previous orthodontic treatment need), and anxiety and depression. The "affective relationship" was considered when individuals reported dating, marriage, or stable union.

\section{TMD Symptoms}

The Diagnostic Criteria for Temporomandibular Disorders (DC/TMD) is an instrument used to evaluate an individual's TMD symptoms ${ }^{13}$. The assessment consists of 14 items related to pain, headache, TMJ noise, open- and closed-mouth jaw locking. The responses are binomial (yes/no). In this study, if the individual answered yes to any of the questions, TMD symptom was considered.

\section{Anxiety and Depression}

The Hospital Anxiety and Depression Scale (HADS) ${ }^{14}$ was used to identify and measure the intensity of anxiety and depression. HADS consists of 14 items divided into two scales, in which seven items measure anxiety (HADS-A) and seven others measure depression (HADS-D). The anxiety and depression evaluated are separated, and each item is classified from 0 to 3 , depending on the response. The maximum score is 21 points for each scale, as follows: scores from 0 to 7 absence of anxiety or depression, 8 to 10 potential anxiety or depression, and above 11 the presence of anxiety or depression ${ }^{15}$. The version used was validated for the Portuguese language ${ }^{16}$.

\section{Orthodontic Treatment Need}

All individuals had their occlusal clinical condition assessed using the Index of Orthodontic Treatment Need (IOTN) ${ }^{17}$. For the clinical examination, the examiner, using all personal protective equipment, used a disposable lip retractor, flashlight, and WHO 621 clinical periodontal probe (Campo Mourão, PA, Brazil), with the individuals seated in an environment with natural light. Only the most severe occlusal change served as a base for classifying the treatment need of individuals ${ }^{17}$. The index determined the orthodontic treatment need (levels 1 through 5) of individuals. For data analysis, levels from 1 to 3 were classified as no need for orthodontic intervention, and levels from 4 to 5 represented treatment need.

\section{Training and Calibration Exercise}

Clinical examinations were performed by a single calibrated examiner, who participated in theoretical training exercises and clinical calibration based on the criteria proposed by the index. Theoretical training for the requirements evaluated by the IOTN was carried out in plaster models to discuss the clinical characteristics of each condition evaluated. For clinical calibration, the researcher examined 20 subjects who did not participate in the primary study sample separately to determine intra-examiner agreement. The Kappa coefficient exceeded 0.92 for the assessment of malocclusion. 


\section{Statistical Analysis}

Simple logistic regression models were adjusted to each independent variable and the outcome variable of the presence of TMD, estimating crude odds ratio with the $95 \%$ confidence intervals. The variables with $\mathrm{p}<0.20$ in the crude analyses were investigated in a multiple logistic regression model, remaining in the variables with $p \leq 0.10$. The associations between each TMD symptom and the variables studies were also assessed using the Chi-square test. The analyses were performed in the R software (R Foundation for Statistical Computing, Vienna, Austria) at a $5 \%$ significance level.

\section{RESULT}

A total of 395 young adults with a mean age of 22 years $( \pm 3.3)$ participated in this study. Demographic, use of medication for continuous and/or sporadic pain, orthodontic characteristics, anxiety, depression, and TMD symptoms data are presented in Table 1.

Table 1 also shows the associations between TMD (yes/no), and the variables studied. There was no significant association of TMD symptoms with gender, age, presence of children, medication use for pain, previous orthodontic treatment, orthodontic treatment need, anxiety, and depression ( $p>0.05$ ). However, individuals who reported no affective relationship are 1.78 (95\%CI: 0.99-3.17) times more likely to present some TMD symptom.

Table 1. Associations between the TMD and the variables studied

\begin{tabular}{|c|c|c|c|c|c|c|c|c|}
\hline \multirow[t]{2}{*}{ Variable } & \multirow[t]{2}{*}{ Categories } & \multirow[t]{2}{*}{ n(\%) } & \multicolumn{2}{|c|}{ TMD } & \multirow[t]{2}{*}{$\begin{array}{c}\text { \$Crude OR } \\
\text { ( } \# 5 \% \mathrm{CI})\end{array}$} & \multirow[t]{2}{*}{ p-value } & \multirow{2}{*}{$\begin{array}{c}\begin{array}{c}\text { \$Final } \\
\text { model OR }\end{array} \\
(\# 95 \% \mathrm{CI})\end{array}$} & \multirow[t]{2}{*}{ p-value } \\
\hline & & & $\begin{array}{c}\text { Absence } \\
\text { n (\%) }\end{array}$ & $\begin{array}{c}\text { Presence }^{*} \\
\text { n (\%) }\end{array}$ & & & & \\
\hline \multirow[t]{2}{*}{ Gender } & Male & 103 & $23(22.3)$ & 80 (77.7) & Ref & & & \\
\hline & Female & 292 & $60(20.6)$ & 232 (79.4) & $1.11(0.64-1.92)$ & 0.7028 & & \\
\hline \multirow[t]{2}{*}{ Age } & $\leq 22$ years & 211 & $38(18.0)$ & $173(82.0)$ & $1.47(0.91-2.40)$ & 0.1178 & & \\
\hline & $>22$ years & 184 & $45(24.5)$ & $139(75.5)$ & Ref & & & \\
\hline Affective & No & 324 & 62 (19.1) & 262 (80.9) & $1.78(0.99-3.17)$ & 0.0525 & 1.78 (0.99- & 0.0525 \\
\hline relationship & Yes & $71(18.0)$ & $21(29.6)$ & $50(70.4)$ & Ref & & Ref & \\
\hline \multirow[t]{2}{*}{ Children } & No & 321 & $63(19.6)$ & $258(80.4)$ & $1.52(0.85-2.72)$ & 0.1606 & & \\
\hline & Yes & 74 (18.7) & $20(27.0)$ & $54(73.0)$ & Ref & & & \\
\hline Medication use & No & 312 & $70(24.4)$ & 242 (77.6) & Ref & & & \\
\hline orofacial pain & Yes & $83(21.0)$ & 13 (15.7) & 70 (84.3) & $1.56(0.81-2.98)$ & 0.1808 & & \\
\hline Previous & No & 123 & $24(19.5)$ & 99 (80.5) & Ref & & & \\
\hline treatment & Yes & 272 & $59(21.7)$ & 213 (78.3) & $0.88(0.52-1.49)$ & 0.6227 & & \\
\hline Orthodontic & No need (1-3) & 339 & $69(20.4)$ & $270(79.6)$ & Ref & & & \\
\hline Treatment need & With need $(>3)$ & $56(14.2)$ & $14(25.0)$ & $42(75.0)$ & $0.77(0.40-1.48)$ & 0.4301 & & \\
\hline \multirow[t]{2}{*}{ Anxiety } & No (HADS & 272 & 59 (21.7) & 213 (78.3) & Ref & & & \\
\hline & Yes (HADS & 123 & $24(19.5)$ & 99 (80.5) & $1.14(0.67-1.94)$ & 0.6227 & & \\
\hline \multirow[t]{2}{*}{ Depression } & No (HADS & 348 & $73(21.0)$ & $275(79.0)$ & Ref & & & \\
\hline & Yes (HADS & 47 (11.9) & $10(21.3)$ & 37 (78.7) & $0.98(0.47-2.07)$ & 0.9621 & & \\
\hline
\end{tabular}

*Reference category for the outcome variable. ${ }^{\$}$ Odds ratio. "Confidence interval.

Table 2 presents the associations between TMD symptoms and the variables studied. There is a higher frequency of individuals with closed-mouth jaw locking among those using medication 
for pain $(\mathrm{p}<0.05)$. There was also a higher rate of open-mouth jaw locking among those with children and treatment needs.

Table 2. Associations between TMD symptoms and the variables studied

\begin{tabular}{|c|c|c|c|c|c|c|c|c|c|c|c|}
\hline \multirow{4}{*}{ Variable } & \multirow{4}{*}{ Categories } & \multirow{3}{*}{$\begin{array}{c}\text { Presence } \\
\text { of } \\
\text { facial } \\
\text { pain }\end{array}$} & \multirow{4}{*}{$\begin{array}{c}\text { p- } \\
\text { value }\end{array}$} & \multirow{3}{*}{$\begin{array}{c}\text { Presence } \\
\text { of } \\
\text { headache }\end{array}$} & \multirow{4}{*}{$\begin{array}{c}\text { p- } \\
\text { value }\end{array}$} & \multirow{3}{*}{$\begin{array}{c}\text { Presence } \\
\text { of } \\
\text { noise }\end{array}$} & \multirow{4}{*}{$\begin{array}{c}\text { p- } \\
\text { value }\end{array}$} & Presence & \multirow{4}{*}{$\begin{array}{c}\text { p- } \\
\text { value }\end{array}$} & Presence & \multirow{4}{*}{$\begin{array}{c}\text { p- } \\
\text { value }\end{array}$} \\
\hline & & & & & & & & $\begin{array}{l}\text { closed- } \\
\text { mouth }\end{array}$ & & $\begin{array}{l}\text { open- } \\
\text { mouth }\end{array}$ & \\
\hline & & & & & & & & $\begin{array}{c}\text { jaw } \\
\text { locking }\end{array}$ & & $\begin{array}{c}\text { jaw } \\
\text { locking }\end{array}$ & \\
\hline & & n (\%*) & & n (\%) & & n (\%) & & n (\%) & & n (\%) & \\
\hline \multirow[t]{2}{*}{ Sex } & Male & $56(54.4)$ & 0.2677 & $49(47.6)$ & 0.6784 & $48(46.6)$ & 0.2008 & $35(34.0)$ & 0.1406 & $13(12.6)$ & 0.5108 \\
\hline & Female & $177(60.6)$ & & $132(45.2)$ & & 115 (39.4) & & 77 (26.4) & & $30(10.3)$ & \\
\hline \multirow[t]{2}{*}{ Age } & $\leq 22$ years & $127(60.2)$ & 0.6029 & $98(46.4)$ & 0.7902 & 83 (39.3) & 0.4042 & $60(28.4)$ & 0.9693 & $22(10.4)$ & 0.7535 \\
\hline & $>22$ years & $106(57.6)$ & & $83(45.1)$ & & $80(43.5)$ & & $52(28.3)$ & & $21(11.4)$ & \\
\hline \multirow{4}{*}{$\begin{array}{c}\text { Affective } \\
\text { relationship } \\
\text { Children }\end{array}$} & Yes & 40 (56.3) & 0.6163 & $28(39.4)$ & 0.2331 & 25 (35.2) & 0.2525 & $21(29.6)$ & 0.8007 & $9(12.7)$ & 0.5929 \\
\hline & Not married & $193(59.6)$ & & 153 (47.2) & & $138(42.6)$ & & 91 (28.1) & & $34(10.5)$ & \\
\hline & No & $193(60.1)$ & 0.3385 & $151(47.0)$ & 0.3117 & $132(41.1)$ & 0.9032 & $88(27.4)$ & 0.3879 & $30(9.4)$ & 0.0407 \\
\hline & Yes & $40(54.0)$ & & $30(40.5)$ & & 31 (41.9) & & $24(32.4)$ & & $13(17.6)$ & \\
\hline \multirow{2}{*}{$\begin{array}{c}\text { Medication } \\
\text { pain }\end{array}$} & No & $181(58.0)$ & 0.4452 & $142(45.5)$ & 0.8105 & 130 (41.7) & 0.7537 & $81(26.0)$ & 0.0408 & $30(9.6)$ & 0.1159 \\
\hline & Yes & $52(62.6)$ & & $39(47.0)$ & & 33 (39.8) & & 31 (37.4) & & 13 (15.7) & \\
\hline \multirow{2}{*}{$\begin{array}{l}\text { Previous } \\
\text { treatment }\end{array}$} & No & 76 (61.8) & 0.4466 & 63 (51.2) & 0.1477 & 54 (43.9) & 0.4741 & 35 (28.5) & 0.9761 & $14(11.4)$ & 0.8314 \\
\hline & Yes & 157 (57.7) & & $118(43.4)$ & & $109(40.1)$ & & 77 (28.3) & & 29 (10.7) & \\
\hline \multirow{2}{*}{$\begin{array}{c}\text { Orthodontic } \\
\text { treatment }\end{array}$} & No need & 199 (58.7) & 0.7767 & $154(45.4)$ & 0.6982 & $136(40.1)$ & 0.2542 & 93 (27.4) & 0.3178 & $32(9.4)$ & 0.0231 \\
\hline & With need & 34 (60.7) & & $27(48.2)$ & & 27 (48.2) & & 19 (33.9) & & $11(19.6)$ & \\
\hline \multirow[t]{2}{*}{ Anxiety } & No & 155 (57.0) & 0.2290 & $128(47.1)$ & 0.4634 & $113(41.5)$ & 0.8673 & 71 (26.1) & 0.1398 & $30(11.0)$ & 0.8918 \\
\hline & Yes & $79(63.4)$ & & $53(43.1)$ & & $50(40.6)$ & & 41 (33.3) & & $13(10.6)$ & \\
\hline \multirow[t]{2}{*}{ Depression } & No & 206 (59.2) & 0.8191 & $162(46.6)$ & 0.4288 & $140(40.2)$ & 0.2551 & 97 (27.9) & 0.5640 & $36(10.3)$ & 0.3473 \\
\hline & Yes & 27 (57.4) & & $19(40.4)$ & & 23 (48.9) & & 15 (31.9) & & 7 (14.9) & \\
\hline
\end{tabular}

*Percentage with presence in each category.

\section{DISCUSSION}

This cross-sectional study assessed the impact of the affective relationship on TMD symptoms among young adults. According to the World Health Organization ${ }^{18}$, young adults have considered individuals aged 20 through 40 years. The highest prevalence of TMD symptoms is observed in young women in an age group attributed to stress, social and cultural behavior, and hormonal characteristics $7,9,19$. Therefore, this study included a sample of volunteers aged 20 through 30 years to eliminate age as a confounding factor.

The results showed that affective relationships in adult life might be associated with the reporting of TMD symptoms, and we highlight that the previous literature has no information on such association. However, affective relationships are essential within the emotional context of individuals and deserve attention because they are inseparable from human development. The present study showed that individuals without a stable affective relationship are more likely to report TMD symptoms, but the association needs to be better understood.

The sociodemographic variables such as gender and age group did not affect TMD symptoms, corroborating with previous studies ${ }^{20,21}$. As for sexual dimorphism, the literature shows different results 22,23 , because women present more TMD symptoms than men. The hypothesis for such difference potentially refers to the age group of the sample studied, and the method applied. The 
present study was careful to include the age group most affected by TMD, between 20 and 30. In Oberoi et al. ${ }^{22}$ study the age group ranged between 30 and 65 years and Ferreira et al ${ }^{23}$. assessed individuals between 19 and 40. Moreover, the sample by Ferreira et al. ${ }^{23}$ was considered convenient because it was taken from medical records, leaving the uncertainty of whether women present more pain or whether men may present the same frequency and incidence of pain without having sought care.

In the present study, few individuals reported using some medication for controlling orofacial pain continuously or sporadically, but almost all individuals presented some TMD symptoms. Thus, it is suggested ${ }^{4}$ the need for investigating comorbidity factors in TMD patients to determine the best treatment strategy. The sensitization of the central nervous system is an amplification of the neural signaling that induces hyperalgesia, in which pain may not be controlled with peripheral action therapy but instead with medications that work on the central nervous system 4 .

Among the individuals assessed, 68.9\% reported having been subjected to previous orthodontic treatment, from which $78.3 \%$ presented some TMD symptom, but without statistical significance. This finding corroborates a previous study ${ }^{10}$, which did not identify such an association even though many orthodontic patients with TMD symptoms were observed. According to current systematic reviews ${ }^{11,24}$, the literature does not report the association between TMD and occlusion, suggesting that orthodontics neither causes nor cures TMD, but it also does not prevent the further development of the disorder. Moreover, it is known that invasive dental therapies such as orthodontic treatment are not recommended for either treating or preventing TMD 25 .

The findings of this study showed that anxiety and depression did not affect the report of TMD symptoms. However, $31.1 \%$ of the sample presented anxiety, and some individuals with anxiety $(80.5 \%)$ reported TMD symptoms. Likewise, $11.9 \%$ of individuals had depression, of which $78.7 \%$ had some TMD symptoms. Previous studies correlated comorbidities, such as anxiety and depression, and other psychological factors to TMD ${ }^{1,4,9}$, which was the reason for studying such variables. Psychosocial factors, somatization, depression, and catastrophization represent risk factors for the long-term persistence of TMD ${ }^{4}$.

As for the limitations, the cross-sectional study design prevents the establishment of a causeand-effect relationship. Furthermore, no scale was used to measure anxiety and stress in the present study, which can be considered a limitation, but future studies integrating this characterization should be developed. A longitudinal study is suggested to assess the influence of variables on TMD symptoms over time.

In general, psychosocial and sociodemographic factors may be associated with TMD symptoms to some extent. Therefore, it is essential to assess the risk factors correlated with TMD to reduce discomfort and improve the quality of life of individuals and guide the treatment strategy for TMD symptoms.

\section{CONCLUSION}

In conclusion, affective relationships showed an association with TMD symptoms in young adults.

\section{REFERENCES}

1. Augusto VG, Perina KCB, Penha DSG, Santos DCA, Oliveira VAS. Temporomandibular dysfunction, stress and common mental disorder in university students. Acta Ortop Bras. 2016 Nov-Dec;24(6):3303. http://dx.doi.org/10.1590/1413-785220162406162873. PMid:28924361. 
2. da Silva MF, Vedovello SAS, Vedovello M Fo, Venezian GC, Valdrighi HC, Degan VV. Temporomandibular disorders and quality of life among 12-year-old schoolchildren. Cranio. 2017 Nov;35(6):392-6. http://dx.doi.org/10.1080/08869634.2016.1248590. PMid:27796174.

3. Jounger SL, Christidis N, Svensson P, List T, Ernberg M. Increased levels of intramuscular cytokines in patients with jaw muscle pain. J Headache Pain. 2017 Dec;18(1):30. http://dx.doi.org/10.1186/s10194-017-0737-y. PMid:28243900.

4. Visscher CM, van Wesemael-Suijkerbuijk EA, Lobbezoo F. Is the experience of pain in patients with temporomandibular disorder associated with the presence of comorbidity? Eur J Oral Sci. 2016 Oct;124(5):459-64. http://dx.doi.org/10.1111/eos.12295. PMid:27669668.

5. De La Torre Canales G, Câmara-Souza MB, Muñoz Lora VRM, Guarda-Nardini L, Conti PCR, Rodrigues Garcia RM, et al. Prevalence of psychosocial impairment in temporomandibular disorder patients: a systematic review. J Oral Rehabil. 2018 Nov;45(11):881-9. http://dx.doi.org/10.1111/joor.12685. PMid:29972707.

6. Davis DM, Fiske J, Scott B, Radford DR. The emotional effects of tooth loss: a preliminary quantitative study. Br Dent J. 2000 May;188(9):503-6. http://dx.doi.org/10.1038/sj.bdj.4800522. PMid:10859849.

7. Muñoz Lora VRM, De la Torre Canales G, Gonçalves LM, Meloto CB, Barbosa CMR. Prevalence of temporomandibular disorders in postmenopausal women and relationship with pain and HRT. Braz Oral Res. 2016 Aug;30(1):e100. PMid:27556676.

8. Chatzopoulos GS, Sanchez M, Cisneros A, Wolff LF. Prevalence of temporomandibular symptoms and parafunctional habits in a university dental clinic and association with gender, age, and missing teeth. Cranio. 2019 May;37(3):159-67. http://dx.doi.org/10.1080/08869634.2017.1399649. PMid:29143569.

9. Chisnoiu AM, Picos AM, Popa S, Chisnoiu PD, Lascu L, Picos A, et al. Factors involved in the etiology of temporomandibular disorders: a literature review. Clujul Med. 2015;88(4):473-8. PMid:26732121.

10. Nokar S, Sadighpour L, Shirzad H, Shahrokhi Rad A, Keshvad A. Evaluation of signs, symptoms, and occlusal factors among patients with temporomandibular disorders according to Helkimo index. Cranio. 2019 Nov;37(6):383-8. http://dx.doi.org/10.1080/08869634.2018.1449781. PMid:29602287.

11. Rinchuse DJ, Greene CS. Scoping review of systematic review abstracts about temporomandibular disorders: Comparison of search years 2004 and 2017. Am J Orthod Dentofacial Orthop. 2018 Jul;154(1):35-46.e9. http://dx.doi.org/10.1016/j.ajodo.2017.12.011. PMid:29957316.

12. Melo GM, Barbosa FS. Parafunção x DTM: a influência dos hábitos parafuncionais na etiologia das desordens temporomandibulares. POS- Prespect. Oral Sci. 2009;1(1):43-8.

13. Schiffman E, Ohrbach R, Truelove E, Look J, Anderson G, Goulet J-P, et al. Diagnostic criteria for temporomandibular disorders (DC/TMD) for clinical and research applications: recommendations of the International RDC/TMD Consortium Network and Orofacial Pain Special Interest Group. J Oral Facial Pain Headache. 2014;28(1):6-27. http://dx.doi.org/10.11607/jop.1151. PMid:24482784.

14. Zigmond AS, Snaith RP. The hospital anxiety and depression scale. Acta Psychiatr Scand. 1983 Jun;67(6):361-70. http://dx.doi.org/10.1111/j.1600-0447.1983.tb09716.x. PMid:6880820.

15. Minghelli B, Morgado M, Caro T. Association of temporomandibular disorder symptoms with anxiety and depression in portuguese college students. J Oral Sci. 2014 Jun;56(2):127-33. http://dx.doi.org/10.2334/josnusd.56.127. PMid:24930749.

16. Botega NJ, Barros MBA, Oliveira HB, Dalgalarrondo P, Marín-León L. Suicidal behavior in the community: prevalence and factors associated with suicidal ideation. Braz J Psychiatry. 2005 Mar;27(1):45-53. http://dx.doi.org/10.1590/S1516-44462005000100011. PMid:15867983.

17. Brook PH, Shaw WC. The development of an index of orthodontic treatment priority. Eur J Orthod. 1989 Aug;11(3):309-20. http://dx.doi.org/10.1093/oxfordjournals.ejo.a035999. PMid:2792220. 
18. World Health Organization. Young people's health: a challenge for society. Report of WHO study group on young people and health for all by the year 2000. Geneva: WHO; 1986. (Technical Report Series; no. 731).

19. Qvintus V, Sipilä K, Le Bell Y, Suominen AL. Prevalence of clinical signs and pain symptoms of temporomandibular disorders and associated factors in adult Finns. Acta Odontol Scand. 2020 Oct;78(7):515-21. http://dx.doi.org/10.1080/00016357.2020.1746395. PMid:32286898.

20. Egermark I, Magnusson T, Carlsson GE. A 20-year follow-up of signs and symptoms of temporomandibular disorders and malocclusions in subjects with and without orthodontic treatment in childhood. Angle Orthod. 2003 Apr;73(2):109-15. PMid:12725365.

21. Karibe H, Goddard G, Shimazu K, Kato Y, Warita-Naoi S, Kawakami T. Comparison of self- reported pain intensity, sleeping difficulty, and treatment outcomes of patients with myofascial temporomandibular disorders by age group: a prospective outcome study. BMC Musculoskelet Disord. 2014 Dec;15(1):423. http://dx.doi.org/10.1186/1471-2474-15-423. PMid:25496226.

22. Oberoi SS, Hiremath SS, Yashoda R, Marya C, Rekhi A. Prevalence of various orofacial pain symptoms and their overall impact on quality of life in a tertiary care hospital in India. J Maxillofac Oral Surg. 2014 Dec;13(4):533-8. http://dx.doi.org/10.1007/s12663-013-0576-6. PMid:26225024.

23. Ferreira CLP, Silva MAMR, Felício CM. Signs and symptoms of temporomandibular disorder in women and men. CoDAS. 2016 Jan-Feb;28(1):17-21. http://dx.doi.org/10.1590/2317-1782/20162014218. PMid:27074184.

24. Manfredini D, Lombardo L, Siciliani G. Temporomandibular disorders and dental occlusion. A systematic review of association studies: end of an era? J Oral Rehabil. 2017 Nov;44(11):908-23. http://dx.doi.org/10.1111/joor.12531. PMid:28600812.

25. Sousa ST, de Mello VVC, Magalhães BG, Morais MPLA, Vasconcelos MMVB, Caldas AF Jr, et al. The role of occlusal factors on the occurrence of temporomandibular disorders. Cranio. 2015 Jul;33(3):211-6. http://dx.doi.org/10.1179/2151090314Y.0000000015. PMid:25027731.

\section{CONFLICTS OF INTERESTS}

The authors declare no conflicts of interest.

\section{*CORRESPONDING AUTHOR}

Silvia Amélia Scudeler Vedovello, FHO - Centro Universitário Hermínio Ometto, Faculdade de Odontologia de Araras, Departamento de Ortodontia, Av. Dr. Maximiliano Baruto, 500, Jardim Universitário, 13607-339 Araras - SP, Brasil, e-mail: silviavedovello@gmail.com 